\title{
Chapter 14 \\ Relationship Between Emissions Trading System and the 2030 Agenda for Sustainable Development
}

\author{
Gustavo Sosa-Nunez
}

\begin{abstract}
With the Paris Agreement and through Nationally Determined Contributions, nation-states have agreed to reduce their emissions of greenhouse gases. Some of them have approached this aspect by setting emission trading systems. In some cases, it is in the regional and sub-national levels where these types of developments are taking place. The relevance of this market-based instrument is increasing over time, to the point of being regarded as a cornerstone of climate change mitigation strategies, despite the lack of global agreement on the matter. The importance of emission trading systems, however, can be observed when assessing their relevance for achieving the 2030 Agenda for Sustainable Development. Implementing them can, and should, assist in reaching diverse targets of different Sustainable Development Goals. This is the case of the goals related to energy, economic growth, inclusive industrialization, sustainable cities, sustainable production and consumption patterns, marine and land life, as well as the climate itself. Then, the relevance of emission trading systems can be observed throughout the whole 2030 Agenda. It is thus in this context that this contribution aims to assess the manner in which this relationship takes place in the global fora and in Mexico. A key argument is that there should be the participation of a wider set of sectors and actors.
\end{abstract}

Keywords Emission trading system $\cdot$ Mexico $\cdot 2030$ Agenda $\cdot$ Sustainable development goals

\section{Introduction}

The main objective of an Emission Trading System (ETS) is to reduce Greenhouse Gas (GHG) emissions in a cost-effective way without damaging the competitiveness of participating sectors and actors (European Commission 2015). The creation of this market-based instrument is aimed at complying with commitments made at the international level to tackle climate change, essentially the 2015 Paris Agreement, in

\author{
G. Sosa-Nunez $(\otimes)$ \\ Instituto Mora-CONACYT, Mexico City, Mexico \\ e-mail: gsosa@institutomora.edu.mx
}


which technological innovation and energy efficiency are essential. To achieve this, it is crucial to measure, report, and verify emissions reductions.

There is a disparity between different ETS according to their geographical location, the type of GHG emissions to consider, and participating sectors. However, they all share the same goal. Now it is Mexico's turn to develop its own ETS. The pilot programme currently in place offers insight about the road the country is planning to follow, and the different chapters conforming to this book provide accounts from different academic approaches about what is coming next, including expectations and areas of opportunity.

It is in this sense that the links between ETS and the 2030 Agenda should be explored. Even when ETS aims at reducing GHG emissions, a relationship with different Sustainable Development Goals (SDGs) exists beyond climate. The underlying rationale is that ETS could gain greater presence and importance in government circles if they were to acknowledge that, by implementing this type of market-based instrument, a better implementation of the 2030 Agenda could happen. Of course, this is an argument that should be explored further, as the content of this contribution shows only initial findings.

In this context, the first section presents a general background of ETS, stating their relevance, followed by a description of the 2030 Agenda, as well as the links that the author observes between SDGs and ETS. Afterwards, the case of Mexico is presented, commenting broadly on the ETS pilot programme currently in place, the national approach to the 2030 Agenda, and the links that are observable as things stand now. Lastly, there are conclusions commenting on the impact that the ETS pilot programme has on the 2030 Agenda, as well as suggestions on how to move forward when the pilot programme transitions to the operative phase.

\section{ETS Background}

There are many ETS across the world with different features. The one developed by the European Union (EU) stands out, as it is the largest market for trading Greenhouse Gases (GHGs) emissions and is its flagship climate change mitigation policy (Jones 2013). It is also the first multinational cap-and-trade system that has been seen as a prototype for a global scheme, as its participants - that is, member statespresent significant disparities in economic circumstance, institutional development, and political will (Ellerman 2010). It includes the power sector, energy-intensive industry, and commercial aviation (European Commission 2020).

Another is the Regional Greenhouse Gas Initiative (RGGI), which is the first mandatory market-based programme in the United States to cap and reduce carbon dioxide $\left(\mathrm{CO}_{2}\right)$ emissions from the power sector. It is a cooperative initiative of the New England and Mid-Atlantic States (RGGI 2020). There is also the Western Climate Initiative (WCI), which is a collaboration of independent jurisdictions with GHG trading programmes between California, USA, and the Provinces of Québec and Nova Scotia, in Canada (WCI 2020). 
Asia also has its cases. In Japan, the Tokyo Metropolitan Area is the country's first mandatory ETS and is linked to the Saitama ETS, in which participants are factories, buildings, and other facilities that consume large quantities of fossil fuels (ICAP 2020a). For its part, South Korea launched East Asia's first nationwide mandatory ETS and the second-largest carbon market after the EU ETS (ICAP 2020b). It includes direct GHG emissions and indirect emissions coming from electricity consumption. China has also recently implemented a national ETS, which builds on the experience of having carried seven regional pilot programmes (ETS-China 2020).

Down south, Australia also developed an ETS, in which credits could be obtained via a carbon farming initiative where farmers were paid to maintain their land as carbon sinks; although this scheme did not last due to political reasons (Atchison 2020). New Zealand also has its own ETS, which creates financial incentives for businesses to reduce their emissions and landowners to earn money by planting forests that become carbon sinks (New Zealand's Ministry for the Environment 2019). This case is also an interesting one because it includes the majority of economic sectors: forestry, waste, industrial processes, stationary energy, fossil fuels, and synthetic gases.

Beyond political jurisdictions, there is the Carbon Offsetting and Reduction Scheme for International Aviation (CORSIA), which is a global scheme for the global international aviation industry, and States adhere as members (ICAO 2020).

Newly created programmes can learn from these previous experiences. For example, the EU ETS experience has provided some insights into this market-based instrument, like considering the power sector and large industrial facilities as the first ones for early inclusion in the ETS. However, initial partial coverage should not "preclude a later, more comprehensive system, although the issue will be whether an initial partial approach makes it more difficult to arrive ultimately at comprehensive coverage" (Ellerman 2010, p. 94).

A further lesson is the possibility to move beyond the energy sector to include forests and farming. Another is that companies reducing emissions regard the carbon price as a competitive advantage; such price is too low to foster technological innovation, and companies focusing on reducing GHG emissions are reducing their costs $\left(\mathrm{MexiCO}_{2} 2019\right)$.

Lastly, a further lesson is that oversupplying emissions allowances contributes to a low carbon price that, in turn, does not stimulate investment in emission reduction measures. If this situation does not happen, then a series of follow-up actions could result in a compelling approach to develop not only strategies for climate change mitigation, but also actions to comply with the 2030 Agenda for Sustainable Development. The resulting spillover effect could in turn help to consider tackling climate change as the cornerstone for worldwide sustainable development. 


\section{Agenda for Sustainable Development}

Since 2000, the United Nations (UN) have developed a series of goals aimed at improving humankind's living conditions. With the Millennium Development Goals (MDGs), which lasted up until 2015, there was the idea to tackle different problems. Out of eight, the seventh MDG emphasized guaranteeing environmental sustainability with no explicit reference to climate change. By the time the MDGs ended, it was acknowledged that climate change was undermining progress and that global $\mathrm{CO}_{2}$ emissions were increasing at a rate of over 50\% since 1990 (UN 2015a). This would locate environmental sustainability at the core of the post-2015 development agenda, which would come jointly with the Paris Agreement.

The 2030 Agenda for Sustainable Development was subscribed in 2015. Trying to overcome the pending issues that the MDGs left, 17 Sustainable Development Goals (SDGs) and 169 targets were issued, aiming at leaving no one behind. Issues would range from poverty, hunger, and health, to land and sea environments, including cities, employment, and economic growth.

Climate change is also considered in the 2030 Agenda. The preamble states the acknowledgement of the United Nations Framework Convention on Climate Change as "the primary international, intergovernmental forum for negotiating the global response to climate change" (UN 2015b, p. 8). For this, it is of utmost importance to accelerate the reduction of global GHG emissions and to adapt to the adverse impacts of climate change. To show commitment, the Agenda dedicates SDG13 to this topic.

However, despite the presence of climate change in the 2030 Agenda, it is through the United Nations Framework Convention on Climate Change (UNFCCC) and the Paris Agreement where efforts to tackle climate change are concentrated. The SDG13 of the 2030 Agenda includes a disclaimer stating this, hence diluting the impact that this SDG could have on climate change combat and the overall Agenda. The SDG Report issued by the United Nations (UN) in 2019 reiterates the importance of reducing GHG emissions, but makes no consideration about the type of instruments or mechanisms to use (UN 2019).

This does not come as a surprise, as the core objective of the Paris Agreement is to tackle climate change and foster the development and implementation of mitigation and adaptation strategies - where market-based instruments like ETS are includedwhile in the 2030 Agenda this topic is one of many to attend, despite its links with different SDGs besides SDG13. The existence of ETS could relate to this context, as this market-based instrument is related essentially to climate change mitigation. However, developing and implementing ETS could assist in achieving a wider range of issues for the Agenda beyond SDG13. 


\section{SDGs Link with ETS}

The 2030 Agenda entails a wide range of issues, like ending poverty and hunger, ensuring healthy lives and quality education, achieving gender equality, accessing water and energy, promoting economic growth, conserving natural sea and inland resources, and promoting peaceful societies, among other objectives (see Appendix 1) (UN 2015b). Many of them can relate to the development and implementation of ETS. It is worth mentioning, though, that the following are broad comments aimed at pointing out links between ETS and the 2030 Agenda, and further research is needed to support these arguments. In fact, each SDG link with ETS would merit a chapter in itself.

The obvious link is with SDG13, as one of the strategies to tackle climate change relates to integrating mitigation measures into national policies. In this sense, setting ETS can be observed as part of a wider climate change policy of a given nation (target 13.2). This also relates to the improvement of education and human and institutional capacity (target 13.3), as well as the increase of capacity for planning and management in the least developed countries (target 13.b).

Besides SDG13, there are links between ETS and other SDGs, which can be observed in two different ways. The first is that some targets of different SDGs can be assisted when implementing ETS. The second is that ETS can be the result of work done around specific SDGs. That is to say, ETS can be either a cause or a consequence of approaches made on specific targets of some SDGs.

Energy is a key factor, which allows for considering SDG7 as having a link. Participating companies looking to be energy efficient (target 7.3) while transitioning to renewable energy - for the sake of GHG emissions reduction-is central to any successful ETS (target 7.2). For this, research and investment in technology are required (target 7.a), to be able to expand infrastructure on the matter (target 7.b).

Being a market-based instrument, ETS should promote sustained, inclusive, and sustainable economic growth, as aimed by SDG8. Participating companies should achieve higher levels of economic productivity through innovation and technological upgrading to reduce GHG emissions (target 8.2), although this can be costly. If this happens, it could lead to decouple economic growth from environmental degradation, as proposed by the 10-Year Framework of Programmes on Sustainable Consumption and Production (10YFP) (targets 8.4 and 12.1, the latter coming from SDG12). If this is attainable, it may result from the development of sustainable industrialization, including the research and adoption of clean and environmentally sound technologies and industrial processes, as proposed by SDG9 (targets 9.2, 9.4, and 9.5).

Transitioning to sustainable and environment-friendly industrialization would imply a positive impact in cities and human settlements where they are located, thus contributing to SDG11. For example, the inclusion of sustainable infrastructure, meaning buildings, could foster the reduction of GHG emissions (target 11.3) and, hence, improve air quality (target 11.6). Besides, if the transport sector participates in ETS, its sustainability could be improved (target 11.2). 
Besides actions suggested by the 10YFP (target 12.1), the implementation of sustainable production patterns, as aimed by SDG12, could assist in reducing GHG emissions of those companies participating in ETS whose production is changing due to innovative technological upgrades. With this, there would be cases in which natural resources are used in a more sustainable and efficient way (target 12.2). Moreover, if cities and human settlements were to participate in ETS as contributing entities, through their governments and representatives, reducing food waste and post-harvest losses could mean a reduction of methane $\left(\mathrm{CH}_{4}\right)$ emissions, which would in turn need to be considered in the set of emissions considered by some ETS. Another aspect of SDG12 that relates heavily with ETS is that, by aiming to reduce GHG emissions, inefficient fossil-fuel subsidies that encourage wasteful consumption could be removed (target 12.c).

On top of the previous comments, if a global ETS were to exist, or regional ones were to be fostered, regardless of the level of country development, some other SDGs could be related, although many of the cases would have to consider the geographical scope, the timeframe, political will, economic context, and citizenry commitment, among other variables.

One can assume that if a reduction in GHG emissions takes place, improvements in health and the SDG3 would also be seen. This could imply a decrease in air pollution, hence reducing the number of deaths and illnesses happening due to this factor (target 3.9). This is because sectors contributing to GHG emissions are also sources of air pollution. Additionally, reducing $\mathrm{CO}_{2}$, which is a GHG, can mean lower emissions of particulate matter, ozone, precursors, and other air pollutants (EPA 2020).

Other SDGs have an indirect link with the development of ETS, and they depend on considering forestry as a component of this type of market-based instrument. This would allow for considering links with SDG15, due to the importance of forests as inland ecosystems that can perform as carbon sinks. It should be the case, as "forestry can either be a source of significant emissions reductions or increasing emissions, depending on what incentive structures are put in place" (Brohé et al. 2009, p. 253). In this sense, their conservation, restoration, and sustainable use (target 15.1), together with halting deforestation and restoring degraded forests (target 15.2), could be actions going in the correct direction if included in ETS, besides being regarded as offset providers. For this, financial support would be necessary (targets 15.a and 15.b). In this context, SDG6 about water is intrinsically related, since forests, as water-related ecosystems, need to be protected and restored (target 6.6).

This is also the case of SDG1, aimed at tackling poverty. Granting equal rights and access to poor and vulnerable people to own land and natural resources (target 1.4) can encourage the participation of a wider set of actors in different ETS. Forest protection for ETS purposes would also help reach other SDG1 targets, like implementing programmes to reduce poverty in the least developed countries (target 1.a), creating related policy frameworks (target 1.b), and building resilience for the poor and reducing their exposure and vulnerability to climate-related extreme events (target 1.5). 
In this context, it is likely that women take the leading role in plenty of cases, due in part to their ownership and control over land and natural resources (target 5.a), as stated by the SDG5, about gender.

If forests are to be included in ETS, agriculture should also be looked at. Agroforestry, forest farming, and mixed farming are examples of interventions in the agriculture sector that can assist to reduce deforestation emissions as well as reducing emissions in the agriculture sector (Carter et al. 2015). That is, although SDG2 relates to ending hunger and achieving food security, it also focuses on the promotion of resilient and sustainable agricultural practices that help maintain ecosystems (target 2.4), which in turn could help to ensure access to food for local communities and a potential trade-related income (targets 2.1 and 2.3).

Would all ETS eventually include a wider range of actors? In developed and middle-income countries, it could be possible, which would lead one to think that not only local communities could participate through the forestry sector, but also smallscale industries and companies, who could promote development-oriented policies and access to financial services (target 8.3), as suggested by SDG8. The more the topic permeates in the society, the more people would be willing to participate, which would allow for establishing links with SDG4, about education. If learners acquire the knowledge and skills needed to promote sustainable development (target 4.7), an increase in public understanding of the topic could take place and, hence, wider participation coming from a broader set of actors would exist. This action could be assisted by an increase of qualified teachers (target 4.c) and by the expansion of scholarships to people interested in learning and deepening knowledge about ETS (target 4.b).

And what about SDG14? Links may appear if ETS were to move from a geographical approach to an emissions-based perspective in which estimated numbers from maritime transportation could be traded in an attempt to reduce marine pollution, regardless of location (target 14.1).

Continuing with potential links, if ETS were to be a global approach to reduce emissions, then it would be necessary to broaden and strengthen the participation of developing countries in institutions of global governance that would deal with the matter (target 16.8). A global carbon price could point in this direction, although this is far from certain for the near future. To make this happen, alliances to foster cooperation in technology, technology transfer, and innovation could assist, as proposed by SDG17 (targets 17.6, 17.7, and 17.8). In turn, all countries would have access to similar information, thus enhancing policy coherence for sustainable development (target 17.14).

Then, as it is observable, many SDGs can relate to ETS, either as the cause of or as consequence from, implementing actions to reach specific targets (see Appendix 2 for a full list of ETS-related SDGs and targets listed in this section). Some links are noticeable, and others require long-term research to assess whether their connection is viable. However, the lifespan of the 2030 Agenda does not address this regard. In spite of this, some findings are conclusive for the current situation of Mexico. 


\section{The Case of Mexico}

Continuing with the idea of pointing at potential links between ETS and different SDGs of the 2030 Agenda, this section aims to identify them for the case of Mexico. To do so, first, it is necessary to contextualize the topic; the reason for which a brief description of the ETS pilot programme recently put in place is provided. Subsequently, Mexico's work around the 2030 Agenda is commented upon, emphasizing on SDG indicators developed for the country and on its National Strategy for the Implementation of the 2030 Agenda. This allows identifying current SDG links with the establishment of the ETS pilot programme.

\section{ETS Pilot Programme}

Mexico has a legal and institutional framework focusing on tackling climate change. The cornerstone is the 2012 General Law on Climate Change, which was amended in 2018 to update the reduction percentages committed in both this legal instrument and the Nationally Determined Contribution (NDC) and it sets the context in which the ETS would exist (LGCC 2012). The federal government is responsible for creating, authorizing, and regulating emissions trading (Art. 7, Fraction IX), while also fostering the competitiveness of companies participating in such trading (Art. 7, Fraction XVIII).

The 2018 amendment entailed the gradual creation of an ETS (Art. 94) that includes a 36-month long pilot programme with no economic effects for participants (Transitory Art. 2). Preparations for Mexico's own ETS were supported by international exchange and experience coming from other parts of the world, as it was the case of California. Germany also assisted Mexico in setting up the National Emissions Registry (RENE), which is a database that collects information on GHG emissions from all major GHG emitting sectors, like energy, industry, transport, and others (IKI Alliance Mexico 2020). Such information would be essential for the ETS pilot programme.

The agreement setting the preliminary basis for the ETS pilot programme was published on 1 October 2019 (Gobierno de México 2019a). Lasting 36 months, the pilot programme began on 1 January 2020 and includes a transition phase towards the operative phase during the whole of 2022. The pilot programme is applicable to energy and industry sectors in cases when their yearly direct emissions surpass 100.000 tons of $\mathrm{CO}_{2}$. Subsectors of the former relate to the production and supply chain of hydrocarbons and electricity. Subsectors of the latter compile a wide range of industries: automotive, cement, chemical, food processing, glass, iron and steel, metallurgical, mining, petrochemical, cellulose and paper, as well as those subsectors that produce emissions out of stationary sources (SEMARNAT 2019). It is worth pointing out that the ETS pilot programme considers only $\mathrm{CO}_{2}$ emissions since it is the most emitted gas in the country (Gobierno de México 2019a). 
The argument to select only energy and industry sectors is that they represent more than $90 \%$ of emissions reported by RENE. The agreement setting the pilot programme states that those sectors and GHG detailed in the LGCC will be added when the operative phase starts. This implies widening the scope of the ETS so that transportation, waste, agriculture, farming, forestry, and other land are considered in the future. It also implies that emissions other than $\mathrm{CO}_{2}$ may be included.

Then, the potential inclusion of a broader range of sectors, once the operative phase starts, allows for consideration of the possibility of Mexico to set the links between the ETS and its approach to the 2030 Agenda. Being in the pilot phase implies a learning process that allows for focusing on areas of opportunities.

\section{Mexico's Approach to the 2030 Agenda}

In accordance with Mexico's usual performance in global affairs, this country adopted the 2030 Agenda at the beginning of 2016. However, the Agenda has not truly permeated public policies, despite the creation of an institutional framework to follow up on the matter and the promotion given to the topic by both governmental and non-governmental actors. Instead, there are broad references to it in governmental development programmes and public discourse, neither of which have the expected impact, mainly due to a lack of interest or indifference that rests on the immediacy of political preferences and government strategies, which focus essentially on social issues. Yet, in 2017, the Office of the Presidency formed a task force that, since then, has discussed the manner in which the Agenda can be implemented and measured.

Including members of the government, academia, private sector, and civil society, the task force assisted to develop a 2018 national strategy to begin the adoption of the Agenda. Nevertheless, it was not until 2019 that a National Strategy for the Implementation of the 2030 Agenda was issued. The task force would also support the National Institute of Statistics and Geography (INEGI) to develop indicators applicable to Mexico to measure SDGs performance.

Taking into account the targets that were identified as potentially having a link with ETS, which were shown in prior sections of this contribution, it is not surprising to argue that all of them could be applicable to Mexico, either explicitly or implicitly. Climate, energy, and industry appear as the obvious connections, but other SDGs are also related. Yet, if indicators to measure those SDG targets do not consider the involvement of ETS, little can be expected to promote the importance of this market-based instrument.

Of the 40 targets previously listed and that seem to relate to the implementation of ETS, indicators were developed in 29 cases (see Gobierno de México 2020). Unsurprisingly, they are mostly unrelated to ETS, except for two indicators of SDG7:

- Indicator 7.2.1.- Share of renewable energy in total final energy consumption.

- Indicator 9.4.1.- Total carbon dioxide emissions by Gross Domestic Product (GDP) by purchasing power parity. 
These indicators could consider the inclusion of ETS - through GHG emissions reduction-as a means to contribute to their respective targets. For this, the meticulous analysis would be required to assess how to incorporate ETS contributions to the indicators, while at the same time keeping them in a side list to show the importance of this market-based instrument not only for the two related indicators, but also for showing their potential relevance for the overall Agenda. It is worth pointing out, however, that if forestry were to be included as a participating sector in the ETS once the operative phase starts, a further indicator could also be considered: indicator 15.1.1, measuring forest area as a proportion of the total area.

Maybe indicators for other SDGs could be developed to assert the importance of ETS for reducing emissions. Again, including forestry could have a spillover effect on other development areas. It would also widen the scope and number of actors and, as a result, it could increase the relevance of programme once its pilot phase ends.

With regard to the National Strategy for the Implementation of the 2030 Agenda, there is only one reference to the relevance of developing an ETS. It is presented as a way to transition to clean technologies that can assist in reducing GHG emissions from productive sectors and, hence, should be promoted and implemented (Gobierno de México 2019b). A further suggestion made in the National Strategy relates to the optimization of a carbon tax that goes beyond the mere fiscal collection, one that is properly destined for emissions reduction.

\section{Comments/Conclusions}

There are different aspects that come to mind when assessing the potential links that ETS can have with the 2030 Agenda SDGs, and the way this can be seen for Mexico. It is important to keep in mind, however, that the ideas expressed in this section require further research for both global and national levels.

To begin with, the development and implementation of ETS can have a spillover effect across many of the SDG targets, an issue that corroborates the transversal nature of the 2030 Agenda. For this to happen, it is essential that the formulation of SDG indicators includes a perspective on the ETS. This implies that whoever participates in the drafting has a clear understanding of the topic. At the same time, those in charge of preparing the ETS operative phase out of the pilot programme should also have the 2030 Agenda in mind. The addition of forests as carbon sinks and the people who manage them can be a turning point, the reason for which assessing the case of New Zealand should be interesting to observe and learn from the experience.

With regard to Mexico, both energy and transport sectors are key for reducing emissions: They are responsible for around three-quarters of the country's total GHG emissions. However, Mexico is not considering the transport sector in the pilot programme. Other sectors should also be included, namely forestry, domestic aviation, management, and public buildings. In addition, other GHG should be included to expand the scope of the emissions. In theory, this will happen with the operative phase, so a close follow-up will be required. 
Considering environmental pollution-including GHG emissions-as economic externalities could assist not only in developing fairer market rules, but also to reach many of the goals of the 2030 Agenda. However, the slow pace and the voluntary approach that characterizes the ETS imply that any potential impact on this type of market instrument to mitigate climate change in Mexico will take place in the distant future. The key message is to foster investments in measures to mitigate emissions, but it is easier said than done. It may be possible that many commercial and industrial entities prefer to pay to pollute and innovate later. This is because it gives them the flexibility to reduce their emissions on their own terms (e.g. decide a timeframe for low carbon investment tailored to their business plan) and do so in the most cost-effective manner.

The aforementioned does not mean that ETS is the panacea to climate change, despite some governments and advocates claiming so. Market-based instruments can be criticized for monetizing the combat to climate change, although this is an ideological perspective that does not hold to the basic premises of the economic system in which we live. Furthermore, due to its market nature, ETS can mean that only those capable of investing in technology to reduce emissions or paying to pollute can persist.

Could ETS foster the creation and preservation of monopolies or oligopolies in specific productive sectors? The best-positioned industries could work together to sideline small competitors that cannot afford to reduce emissions or innovate at the speed, pace, and scope that a wealthier industry can. This is why it is important to broaden the scope of participant actors in ETS. The role of national governments is also up for discussion. They would be expected to regulate monopolies and oligopolies. Advocating for a bigger role from the state, either through incentives or regulations, depends on an environmentally conscious government that commits to the issue. Here, it is necessary to consider another set of variables, like the political party in power, policy preferences, and institutional structure, to cite a few.

Should the invisible hand be fully in charge of ruling this market-based instrument? How to set adequate carbon prices? There are many questions and few answers. Delayed decisions do not contribute to develop the urgent actions necessary to give ETS the importance that the global community is willing to give to them.

Then, it is worth noticing that the ETS is merely one of the many climate change mitigation measures that exist, and focusing on it due to its potential and market-driven perspective can be counterproductive if other measures are sidelined or reduced in importance. Therefore, there is the need to see the whole picture and include more sectors and actors. The consideration of the 2030 Agenda for Sustainable Development can be of assistance to get to this point. 


\section{Annex 1-Sustainable Development Goals of the 2030 Agenda}

Goal 1. End poverty in all its forms everywhere.

Goal 2. End hunger, achieve food security and improved nutrition, and promote sustainable agriculture.

Goal 3. Ensure healthy lives and promote well-being for all at all ages.

Goal 4. Ensure inclusive and equitable quality education and promote lifelong learning opportunities for all.

Goal 5. Achieve gender equality and empower all women and girls.

Goal 6. Ensure availability and sustainable management of water and sanitation for all.

Goal 7. Ensure access to affordable, reliable, sustainable, and modern energy for all.

Goal 8. Promote sustained, inclusive, and sustainable economic growth; full and productive employment; and decent work for all.

Goal 9. Build resilient infrastructure, promote inclusive and sustainable industrialization, and foster innovation.

Goal 10. Reduce inequality within and among countries.

Goal 11. Make cities and human settlements inclusive, safe, resilient, and sustainable.

Goal 12. Ensure sustainable consumption and production patterns.

Goal 13. Take urgent action to combat climate change and its impacts.

Goal 14. Conserve and sustainably use the oceans, seas, and marine resources for sustainable development.

Goal 15. Protect, restore, and promote sustainable use of terrestrial ecosystems, sustainably manage forests, combat desertification, and halt and reverse land degradation and halt biodiversity loss.

Goal 16. Promote peaceful and inclusive societies for sustainable development; provide access to justice for all; and build effective, accountable, and inclusive institutions at all levels.

Goal 17. Strengthen the means of implementation and revitalize the Global Partnership for Sustainable Development. 


\section{Annex 2-ETS-Related SDGs and Targets}

\section{Goal 1. End poverty in all its forms everywhere}

1.4 By 2030, ensure that all men and women, in particular the poor and the vulnerable, have equal rights to economic resources, as well as access to basic services, ownership and control over land and other forms of property, inheritance, natural resources, appropriate new technology, and financial services, including microfinance.

1.5 By 2030, build the resilience of the poor and those in vulnerable situations and reduce their exposure and vulnerability to climate-related extreme events and other economic, social, and environmental shocks and disasters.

1.a Ensure significant mobilization of resources from a variety of sources, including through enhanced development cooperation, in order to provide adequate and predictable means for developing countries, in particular least developed countries, to implement programmes and policies to end poverty in all its dimensions.

1.b Create sound policy frameworks at the national, regional, and international levels, based on pro-poor and gender-sensitive development strategies, to support accelerated investment in poverty eradication actions.

\section{Goal 2. End hunger, achieve food security and improved nutrition, and promote sustainable agriculture}

2.1 By 2030, end hunger and ensure access by all people, in particular the poor and people in vulnerable situations, including infants, to safe, nutritious, and sufficient food all year round.

2.3 By 2030, double the agricultural productivity and incomes of small-scale food producers, in particular women, indigenous peoples, family farmers, pastoralists, and fishers, including through secure and equal access to land, other productive resources and inputs, knowledge, financial services, markets, and opportunities for value addition and non-farm employment.

2.4 By 2030, ensure sustainable food production systems and implement resilient agricultural practices that increase productivity and production; that help maintain ecosystems; that strengthen capacity for adaptation to climate change, extreme weather, drought, flooding, and other disasters; and that progressively improve land and soil quality.

\section{Goal 3. Ensure healthy lives and promote well-being for all at all ages}

3.9 By 2030, substantially reduce the number of deaths and illnesses from hazardous chemicals and air, water, and soil pollution and contamination. 


\section{Goal 4. Ensure inclusive and equitable quality education and promote lifelong} learning opportunities for all

4.7 By 2030, ensure that all learners acquire the knowledge and skills needed to promote sustainable development, including, among others, through education for sustainable development and sustainable lifestyles, human rights, gender equality, promotion of a culture of peace and non-violence, global citizenship, and appreciation of cultural diversity and of culture's contribution to sustainable development.

4.b By 2020, substantially expand globally the number of scholarships available to developing countries, in particular least developed countries, small island developing States, and African countries, for enrolment in higher education, including vocational training and information and communications technology, technical, engineering, and scientific programmes in developed countries and other developing countries.

4.c By 2030, substantially increase the supply of qualified teachers, including through international cooperation for teacher training in developing countries, especially least developed countries and small island developing States.

\section{Goal 5. Achieve gender equality and empower all women and girls}

5.a Undertake reforms to give women equal rights to economic resources, as well as access to ownership and control over land and other forms of property, financial services, inheritance, and natural resources, in accordance with national laws.

\section{Goal 6. Ensure availability and sustainable management of water and sanitation for all}

6.6 By 2020, protect and restore water-related ecosystems, including mountains, forests, wetlands, rivers, aquifers, and lakes.

Goal 7. Ensure access to affordable, reliable, sustainable, and modern energy for all

7.2 By 2030, increase substantially the share of renewable energy in the global energy mix.

7.3 By 2030, double the global rate of improvement in energy efficiency.

7.a By 2030, enhance international cooperation to facilitate access to clean energy research and technology, including renewable energy, energy efficiency, and advanced and cleaner fossil-fuel technology, and promote investment in energy infrastructure and clean energy technology.

7.b By 2030, expand infrastructure and upgrade technology for supplying modern and sustainable energy services for all in developing countries, in particular least developed countries, small island developing States, and landlocked developing countries, in accordance with their respective programmes of support. 


\section{Goal 8. Promote sustained, inclusive, and sustainable economic growth; full and productive employment; and decent work for all}

8.2 Achieve higher levels of economic productivity through diversification, technological upgrading, and innovation, including through a focus on high-value added and labour-intensive sectors.

8.3 Promote development-oriented policies that support productive activities, decent job creation, entrepreneurship, creativity, and innovation, and encourage the formalization and growth of micro-, small-, and medium-sized enterprises, including through access to financial services.

8.4 Improve progressively, through 2030, global resource efficiency in consumption and production and endeavour to decouple economic growth from environmental degradation, in accordance with the 10-Year Framework of Programmes on Sustainable Consumption and Production, with developed countries taking the lead.

\section{Goal 9. Build resilient infrastructure, promote inclusive and sustainable indus- trialization, and foster innovation}

9.2 Promote inclusive and sustainable industrialization and, by 2030 , significantly raise industry's share of employment and gross domestic product, in line with national circumstances, and double its share in the least developed countries.

9.4 By 2030, upgrade infrastructure and retrofit industries to make them sustainable, with increased resource-use efficiency and greater adoption of clean and environmentally sound technologies and industrial processes, with all countries taking action in accordance with their respective capabilities.

9.5 Enhance scientific research and upgrade the technological capabilities of industrial sectors in all countries, in particular developing countries, including, by 2030 , encouraging innovation and substantially increasing the number of research and development workers per 1 million people and public and private research and development spending.

Goal 11. Make cities and human settlements inclusive, safe, resilient, and sustainable

11.2 By 2030, provide access to safe, affordable, accessible, and sustainable transport systems for all, improving road safety, notably by expanding public transport, with special attention to the needs of those in vulnerable situations, women, children, persons with disabilities, and older persons.

11.3 By 2030, enhance inclusive and sustainable urbanization and capacity for participatory, integrated, and sustainable human settlement planning and management in all countries.

11.6 By 2030, reduce the adverse per capita environmental impact of cities, including by paying special attention to air quality and municipal and other waste management. 


\section{Goal 12. Ensure sustainable consumption and production patterns}

12.1 Implement the 10-Year Framework of Programmes on Sustainable Consumption and Production Patterns, all countries taking action, with developed countries taking the lead, taking into account the development and capabilities of developing countries.

12.2 By 2030, achieve the sustainable management and efficient use of natural resources.

12.c Rationalize inefficient fossil-fuel subsidies that encourage wasteful consumption by removing market distortions, in accordance with national circumstances, including by restructuring taxation and phasing out those harmful subsidies, where they exist, to reflect their environmental impacts, taking fully into account the specific needs and conditions of developing countries and minimizing the possible adverse impacts on their development in a manner that protects the poor and the affected communities.

\section{Goal 13. Take urgent action to combat climate change and its impacts}

13.2 Integrate climate change measures into national policies, strategies, and planning.

13.3 Improve education, awareness-raising, and human and institutional capacity on climate change mitigation, adaptation, impact reduction, and early warning.

13.b Promote mechanisms for raising capacity for effective climate change-related planning and management in the least developed countries and small island developing States, including focusing on women, youth, and local and marginalized communities.

Goal 14. Conserve and sustainably use the oceans, seas, and marine resources for sustainable development

14.1 By 2025, prevent and significantly reduce marine pollution of all kinds, in particular from land-based activities, including marine debris and nutrient pollution.

Goal 15. Protect, restore, and promote sustainable use of terrestrial ecosystems, sustainably manage forests, combat desertification, and halt and reverse land degradation and halt biodiversity loss

15.1 By 2020, ensure the conservation, restoration, and sustainable use of terrestrial and inland freshwater ecosystems and their services, in particular forests, wetlands, mountains, and drylands, in line with obligations under international agreements.

15.2 By 2020, promote the implementation of sustainable management of all types of forests, halt deforestation, restore degraded forests, and substantially increase afforestation and reforestation globally.

15.a Mobilize and significantly increase financial resources from all sources to conserve and sustainably use biodiversity and ecosystems. 
15.b Mobilize significant resources from all sources and at all levels to finance sustainable forest management and provide adequate incentives to developing countries to advance such management, including for conservation and reforestation.

Goal 16. Promote peaceful and inclusive societies for sustainable development; provide access to justice for all; and build effective, accountable, and inclusive institutions at all levels

16.8 Broaden and strengthen the participation of developing countries in the institutions of global governance.

\section{Goal 17. Strengthen the means of implementation and revitalize the Global Partnership for Sustainable Development}

\section{Technology}

17.6 Enhance North-South, South-South, and triangular regional and international cooperation on and access to science, technology, and innovation and enhance knowledge sharing on mutually agreed terms, including through improved coordination among existing mechanisms, in particular at the United Nations level, and through a global technology facilitation mechanism.

17.7 Promote the development, transfer, dissemination, and diffusion of environmentally sound technologies to developing countries on favourable terms, including on concessional and preferential terms, as mutually agreed.

17.8 Fully operationalize the technology bank and science, technology and innovation capacity-building mechanism for least developed countries by 2017 and enhance the use of enabling technology, in particular information and communications technology.

Systemic issues-Policy and institutional coherence

17.14 Enhance policy coherence for sustainable development.

\section{References}

Atchison J (2020) Australia's ill-fated emissions trading system. Climate scorecard. 6 Mar 2020. https://www.climatescorecard.org/2020/03/australias-ill-fated-emissions-trading-system/ Accessed 8 June 2020

Brohé A, Eyre N, Howarth N (2009) Carbon markets: an international business guide. Earthscan, London

Carter S, Herold M, Rufino MC, Neumann K, Kooistra L, Verchot L (2015) Mitigation of agricultural emissions in the tropics: comparin forest land-sparing options at the national level. Biogeosciences 12:4809-4025. https://www.cifor.org/knowledge/publication/5630/. Accessed 7 June 2020

European Commission (2015) EU ETS handbook. https://ec.europa.eu/clima/sites/clima/files/docs/ ets_handbook_en.pdf. Accessed 20 Aug 2020 
Ellerman D (2010) The EU emission trading scheme: a prototype global system? In: Aldy JE, Stavins RN (eds) Post-Kyoto international climate policy: implementing architectures for agreement. Cambridge University Press, Cambridge, pp 88-118

EPA (United States Environmental Protection Agency) (2020) Air quality and climate change research. 11 Mar 2020. https://www.epa.gov/air-research/air-quality-and-climate-change-res earch. Accessed 7 June 2020

ETS-China (2020) Emission trading schemes in China. https://ets-china.org/ets-in-china/. Accessed 9 June 2020

European Commission (2020) EU Emissions Trading System (EU ETS). https://ec.europa.eu/ clima/policies/ets_en. Accessed 10 June 2020

Gobierno de México (2020) Indicadores por objetivo y meta [Indicators by goal and target]. Objetivos de desarrollo sostenible. INEGI. http://agenda2030.mx/ODSopc.html?ti=T\&goal=0\& lang=es\#/ind. Accessed 9 June 2020

Gobierno de México (2019a) Acuerdo por el que se establecen las bases preliminares del Programa de Prueba del Sistema de Comercio de Emisiones [Agreement setting the preliminary basis of the emissions trading system pilot program]. Diario Oficial de la Federación (DOF). 1 Oct 2019. https://dof.gob.mx/nota_detalle.php?codigo $=5573934 \&$ fecha $=01 / 10 / 2019$ Accessed 10 June 2020

Gobierno de México (2019b) Estrategia nacional para la implementación de la agenda 2030 [National estrategy for the implementation of the 2030 agenda]. https://www.gob.mx/agenda 2030/documentos/estrategia-nacional-de-la-implementacion-de-la-agenda-2030-para-el-desarr ollo-sostenible-en-mexico. Accessed 10 June 2020

ICAO (International Civil Aviation Organization) (2020) Benefits for CORSIA participation. https://www.icao.int/environmental-protection/Pages/A39_CORSIA_FAQ5.aspx. Accessed 9 June 2020

ICAP (International Carbon Action Partnership) (2020a) Japan-Tokyo cap-and-trade program. Last update: 3 June 2020. https://icapcarbonaction.com/en/?option=com_etsmap\&task=export\& format=pdf\&layout=list\&systems $\% 5 B \% 5 \mathrm{D}=51$. Accessed 9 June 2020

ICAP (International Carbon Action Partnership) (2020b) Korea emissions trading scheme. Last update: 3 June 2020. https://icapcarbonaction.com/en/?option=com_etsmap\&task=export\&for mat=pdf\&layout=list\&systems $\% 5 B \% 5 \mathrm{D}=47$. Accessed 9 June 2020

IKI Alliance Mexico (2020) Preparation of an emission trading system (ETS) in Mexico. International Climate Initiative (IKI). GIZ-BMU. http://iki-alliance.mx/en/portafolio/preparation-ofan-emissions-trading-system-ets-in-mexico/. Accessed 2 June 2020

Jones CW (2013) A report on the European union emissions trading system (EU-ETS). Institute for Global Environmental Strategies. IGES working paper No. 2013-02

LGCC (Ley general de cambio climático) [General law on climate change] (2012) Diario oficial de la federación (DOF). 6 June 2012. Amendment date: 13 July 2018. http://www.diputados.gob. mx/LeyesBiblio/pdf/LGCC_130718.pdf. Accessed 12 May 2020

$\mathrm{MexiCO}_{2}$ (2019) Nota Técnica. Sistema de comercio de emisiones en México [Technical sheet. Emissions trading system in Mexico]. $\mathrm{MexiCO}_{2}$ : Plataforma Mexicana de Carbono. July 2019. http://www.mexico2.com.mx/uploadsmexico/file/NOTA\%20Sistema\%20de\%20C omercio\%20de\%20Emisiones\%20en\%20M\%C3\%A9xico\%20v040719\%203.pdf. Accessed 3 June 2020

New Zealand's Ministry for the Environment (2019) About the New Zealand emissions trading scheme. 18 Dec 2019. https://www.mfe.govt.nz/climate-change/new-zealand-emissions-tradingscheme/about-nz-ets. Accessed 9 June 2020

RGGI (Regional Greenhouse Gas Initiative) (2020) Elements of RGGI. https://www.rggi.org/pro gram-overview-and-design/elements. Accessed 10 June 2020

SEMARNAT (Secretaría de Medio Ambiente y Recursos Naturales) (2019) Programa de prueba del sistema de comercio de emisiones [ETS pilot program]. 27 Nov 2019. https://www.gob.mx/ semarnat/acciones-y-programas/programa-de-prueba-del-sistema-de-comercio-de-emisiones179414. Accessed 14 Apr 2020 
UN (United Nations) (2015a) The millennium development goals report 2015. https://www. un.org/millenniumgoals/2015_MDG_Report/pdf/MDG\%202015\%20rev\%20(July\%201).pdf. Accessed 6 June 2020

UN (United Nations) (2015b) Transforming our world. The 2030 agenda for sustainable development. Resolution A/RES/70/1.21 Oct 2015. https://www.un.org/ga/search/view_doc.asp?sym bol=A/RES/70/1\&Lang=E. Accessed 16 Apr 2020

UN (United Nations) (2019) Sustainable development goals report 2019. New York. https://unstats. un.org/sdgs/report/2019/. Accessed 10 June 2020

WCI (Western Climate Initiative) (2020) Greenhouse gas emissions trading: a cost-effective solution to climate change. https://wci-inc.org/. Accessed 10 June 2020

Open Access This chapter is licensed under the terms of the Creative Commons Attribution 4.0 International License (http://creativecommons.org/licenses/by/4.0/), which permits use, sharing, adaptation, distribution and reproduction in any medium or format, as long as you give appropriate credit to the original author(s) and the source, provide a link to the Creative Commons license and indicate if changes were made.

The images or other third party material in this chapter are included in the chapter's Creative Commons license, unless indicated otherwise in a credit line to the material. If material is not included in the chapter's Creative Commons license and your intended use is not permitted by statutory regulation or exceeds the permitted use, you will need to obtain permission directly from the copyright holder. 